\title{
JUDICIAL ENFORCEMENT OF LABOR ARBITRATORS' AWARDS
}

Despite the large amount which has been written in the field of labor arbitration, one topic has received very little discussion-the problem of judicial enforcement of those labor arbitrators' awards not in conformity with the "law." This Comment will deal with that problem as it may arise where suit is brought to enforce an arbitral award and one of the following defenses is made: enforcement would cause the defendant to violate a statutory prohibition; or the arbitrator disregarded or misapplied a court decision ${ }^{1}$ dealing with a labor contract provision similar to the one at issue. ${ }^{2}$

\section{Commercial Arbitration}

The problem of the role of courts in the enforcement of arbitral awards has arisen in the context of commercial arbitration, ${ }^{3}$ and it seems appropriate to examine the solutions evolved by the courts in this area to see what light they may shed on the question of the proper scope of judicial review over labor arbitrators.

The first significant expression of the role of the courts vis-à-vis an arbitrator was made over a century ago in Burchell $v$. Marsh. ${ }^{4}$ In rejecting the defendants' contention that the award should be set aside, Mr. Justice Grier said :

Arbitrators are judges chosen by the parties to decide the matters submitted to them, finally and without appeal. As a mode of settling disputes, it should receive every encouragement from courts of equity. If the award is within the submission, and contains the honest decision of the arbitrators, after a full and fair hearing of the parties, a court of equity will not set it aside for error, either in law or fact. A contrary course would be a substitution of the judgment of the chancellor in place of the judges chosen by the parties, and would make an award the commencement, not the end, of litigation. ${ }^{5}$

1 This court decision might be either that of a federal court or of a state court applying federal law under $\$ 301$ of the Labor Management Relations Act, 61 Stat. 156 (1947), as amended, 29 U.S.C. \$185 (1964).

2 A separate problem, not discussed in the text of this Comment although treated briefly in note 46 infra, is the situation where suit is brought to compel arbitration and the defense is made that if the arbitrator were to decide for the plaintiff he would be ordering a violation of law.

3 This Comment will maintain at least a verbal distinction by referring to all arbitration other than labor as commercial arbitration.

458 U.S. (17 How.) 344 (1855).

Id. at 349 . 
The similarity between this language and that contained in section 10 of the United States Arbitration Act $^{6}$ is striking. Section 10 reads as follows:

In either of the following cases the United States court in and for the district wherein the award was made may make an order vacating the award upon the application of any party to the arbitration-

(a) Where the award was procured by corruption, fraud, or undue means.

(b) Where there was evident partiality or corruption in the arbitrators, or either of them.

(c) Where the arbitrators were guilty of misconduct in refusing to postpone the hearing, upon sufficient cause shown, or in refusing to hear evidence pertinent and material to the controversy; or of any other misbehavior by which the rights of any party have been prejudiced.

(d) Where the arbitrators exceeded their powers, or so imperfectly executed them that a mutual, final, and definite award upon the subject matter submitted was not made.

(e) Where an award is vacated and the time within which the agreement required the award to be made has not expired the court may, in its discretion, direct a rehearing by the arbitrators.

Of greatest significance here is that the Arbitration Act does not deem an arbitrator's "mistake of law"-i.e., a misapplication or misconstruction of principles of law as announced by courts-a sufficient ground for overturning his decision. The courts have recognized and given effect to this omission. ${ }^{7}$

69 U.S.C. $\$ 10$ (1964). It should be noted at the outset, and will be discussed more fully at note 21 infra, that a court does not review the award of a labor arbitrator under the Arbitration Act but rather under $\$ 301$ of the Labor Management Relations Act, 61 Stat 156 (1947), as amended, 29 U.S.C. $\$ 185$ (1964).

In Elkouri \& Elkouri, How Arbitration Works (2d ed. 1960), there is a discussion of the common law grounds for overturning an arbitral award. These grounds may be profitably compared with $\S 10$ of the Arbitration Act and the language in Burchell. The Elkouris wrote:

The grounds for attacking awards . . a are generally limited to:

1. Fraud, misconduct or partiality by the arbitrator, or gross unfairness in the conduct of the proceedings.

2. Fraud or misconduct by the parties affecting the result.

3. Complete want of jurisdiction in the arbitrator. Also, failure of the arbitrator to stay within his jurisdiction or to carry it out fully-that is, he decides too much or too little.

4. Violation of public policy as by ordering the commission of an unlawful act.

Id. at 26-27.

7 See, e.g., Raytheon Co. v. Rheem Mfg. Co., 322 F.2d 173, 182-83 (9th Cir. 1963); Orion Shipping \& Trading Co. v. Eastern States Petroleum Co., 312 F.2d 299, 300 
Nearly 100 years after the Burchell decision, the Supreme Court again spoke on the problem, in language reminiscent of that used by $\mathrm{Mr}$. Justice Grier. In Wilko v. Swan, ${ }^{8}$ the question arose whether a person who acquired shares of stock which were subject to an agreement to arbitrate must submit to arbitration rather than be entitled to a judicial forum in the first instance. In that case, the Court felt that the policy of the Securities Act of $1933^{\circ}$-the protection of investors-was in conflict with the policy of the Arbitration Act. ${ }^{10}$ The Court held that the petitioner was entitled to a judicial forum in the first instance, giving as its reason the limited scope of judicial review over an arbitral award. Mr. Justice Reed stated: "In unrestricted submissions . . . the interpretations of the law by the arbitrators in contrast to manifest disregard are not subject, in the federal courts, to judicial review for error in interpretation." 11

This statement has given rise to some discussion in the lower federal courts. A recent Ninth Circuit opinion, for example, stated that "manifest disregard of the law" must be something more than an error in the law or the failure of the arbitrator to understand and apply the law. ${ }^{12}$ The court suggested that Mr. Justice Reed used the term to refer to the situation where the arbitrator understands and correctly states the law but then disregards it. ${ }^{13}$

Amicizia Societa Navegazione v. Chilean Nitrate \& Iodine Sales Corp. ${ }^{14}$ a Second Circuit decision, lends some support to this definition. There Judge Clark declared:

The statutory provisions . . . in expressly stating certain grounds for either vacating an award or modifying or correcting it, do not authorize its setting aside on the grounds of erroneous finding of fact or of misinterpretation of law .... [T] misapplication . . . of such rules of contract interpretation does not rise to the stature of a "manifest disregard" of law. ${ }^{15}$

(2d Cir.), cert. denied, 373 U.S. 949 (1963) ; Stef Shipping Corp. v. Norris Grain Co., 209 F. Supp. 249, 254 (S.D.N.Y. 1962) ; General Constr. Co. v. Hering Realty Co., 201 F. Supp. 487, 491 (E.D.S.C. 1962) ; Gramling v. Food Mach. \& Chem. Corp., 151 F. Supp. 853, 857 (W.D.S.C. 1957). But see Jalet, Judicial Review of Arbitration:

The Judicial Attitude, 45 CoRN. L.Q. 519 (1960).

8346 U.S. 427 (1953).

948 Stat. 74 (1933), as amended, 15 U.S.C. \$\$77a-77aa (1964).

10 The policy of the Arbitration Act was stated by the Court to be:

the desirability of arbitration as an alternative to the complications of litigation. The reports of both Houses on that Act stress the need for avoiding the delay and expense of litigation [H.R. Rap. No. 96, 68th Cong., 1st Sess. 1-2 (1924); S. REP. No. 536, 68th Cong., 1st Sess. 3 (1924)], and practice under its terms raises hope for its usefulness both in controversies based on statutes or on standards otherwise created.

346 U.S. at 431-32. (Footnotes omitted.)

11 Id. at 436-37. (Footnotes omitted.)

12 San Martine Companía de Navegación, S.A. v. Saguenay Terminals, Itd.,

293 F.2d 796, 801 (9th Cir. 1961).

13 Ibid.

14274 F.2d 805 (2d Cir.), cert. denied, 363 U.S. 843 (1960).

$15 \mathrm{Id}$. at 808. 
Since in Wilko the Court was faced with the hypothetical failure of an arbitrator to decide in accordance with the provisions of the Securities Act, another interpretation of Mr. Justice Reed's language seems justified. By "manifest disregard," he was referring merely to the situation where an arbitrator ordered one of the parties to commit an illegal act, i.e., one in contravention of the Securities Act. ${ }^{16}$

Under either interpretation it is the extraordinary commercial arbitration award that is overturned for a "mistake of law" 17 -even though the decision of the arbitrator is different from that which the court might have made had it heard the cause in the first instance. Probably the main reason why courts have been unwilling to overturn a "lawless" arbitration award is that the parties have chosen the arbitrator to decide their disputes. ${ }^{18}$ They could have bound him contractually to apply principles of law correctly, but they did not. From this the inference can be drawn that the parties desired an expeditious, impartial solution by an arbitrator rather than a time consuming, "lawful" one by the courts. Thus the courts might be said to be merely enforcing the original intent of the parties. This reasoning is strengthened by acknowledgment of the function which commercial arbitration performs in our society. As stated in Wilko, arbitration avoids the delays and expense of litigation ${ }^{19}$ and, it might be pointed out, lessens the workload of the courts. These advantages would be lost if the scope of review of arbitral awards were broadened.

\section{LABOr Arbitration}

\section{A. Introduction}

In shifting from commercial arbitration to an examination of labor arbitration, the question is whether there are forces operating in the labor area which would justify the courts' reviewing arbitrators' decisions for "mistakes of law" to a greater extent than they do in enforcing commercial arbitration awards. Certainly labor arbitrators are as much creatures of contract as commercial arbitrators, and the function they perform is perhaps even more important. Mr. Justice Goldberg said:

Although labor arbitration has a resemblance to commercial arbitration, in the sense that both arise out of contract, nevertheless, there is a significant difference which basically distinguishes

16 If this is what was meant, it seems unobjectionable. See Evans v. Hudson Coal Co., 165 F.2d 970, 974 (3d Cir. 1948) (dictum). However, to the extent that the "manifest disregard" rule goes beyond an arbitrator's order of an illegal act, it becomes of doubtful validity. Since arbitrators need not write opinions, the restraint of the rule seems academic. Moreover the wisdom of a rule which might induce arbitrators not to write opinions is questionable in light of the benefits generally attributed to opinion writing. See generally MISHKIN \& MORRIS, ON LAw IN CourTs 183-92 (1965).

17 See authorities collected at note 7 supra.

18 Burchell v. Marsh, 58 U.S. (17 How.) 344, 349 (1855).

19 Wilko v. Swan, 346 U.S. 427, 431 (1953). 
the two forms of arbitration. Labor arbitration fulfills one vital function: the substitution of the judgment of a third party for the use of economic force. ${ }^{20}$

In light of this statement it would seem that if there were to be any difference in scope of review between commercial and labor arbitral awards, the courts should review the labor awards even more narrowly than their commercial counterparts. ${ }^{21}$ This reasoning would be conclusive if not for Local 174, Teamsters Union v. Lucas Flour. ${ }^{22}$

Lucas Flour was a suit for damages for breach of a collective bargaining agreement brought by the employer under section 301 of the Labor Management Relations Act, ${ }^{23}$ and the issue was whether the state court was required to apply federal law. Writing for a majority of the Court, Mr. Justice Stewart held that federal law pre-empted the field: "The dimensions of $\S 301$ require the conclusion that substantive principles of federal labor law must be paramount in the area covered by the statute." 24 The Court reasoned that uniformity was necessary in this area because any other result might prove deleterious to the collective bargaining process-uncertainty as to whether a particular state rule or the federal rule would be applied in construing a contract would have a disruptive effect at the bargaining table and perhaps even keep an agreement from being reached.25 Drawing on this reasoning, the contention has been made that there is the same need for uniformity regarding the law to be applied by a labor arbitrator. ${ }^{28}$ In the arbitration situation, it is said, disruption is caused not by uncertainty as to

20 Goldberg, A Supreme Court Justice Looks At Arbitration, 20 ARB. J. 13, 14 (1965). See Mr. Justice Douglas' statement in United Steelworkers of America v. Warrior \& Gulf Nav. Co., 363 U.S. 574, 578 (1960) : "In the commercial case, arbitration is the substitute for industrial strife."

21 It should be noted that while the issue has never been expressly litigated, it seems certain that a court takes jurisdiction of suits involving labor arbitration under $\$ 301$ of the Labor Management Relations Act, 61 Stat. 156 (1947), as amended, 29 U.S.C. \$185 (1964), and would thts in no way be bound by the United States Arbitration Act or the case law which has arisen thereunder. If this proposition were not clear since the Supreme Court's decision in Textile Workers Union v. Lincoln Mills, 353 U.S. 448 (1957), it is made clear by a comparison of the Second Circuit's opinion in Robert Lawrence Co. v. Devonshire Fabrics, Inc., 271 F.2d 402 (2d Cir. 1959), cert. granted, 362 U.S. 909, dismissed per stipulation, 364 U.S. 801 (1960), with The Steelworkers' Trilogy, discussed at notes 27-31 infra. In Lawrence, where a commercial arbitration agreement was at issue, the Second Circuit held that the validity and interpretation of the agreement must be determined by the federal substantive law of arbitration as expressed in the Arbitration Act. The Trilogy, on the other hand, involving disputes regarding labor arbitration, looked to the Labor Management Relations Act, specifically to \$301, for guidance with regard to the substantive law to be applied. However, this should not be taken to imply that a federal court cannot look to the Arbitration Act or its case law for guidance. The proposition put forward is merely that the court is not bound by such law.

22369 U.S. 95 (1962).

2361 Stat. 156 (1947), as amended, 29 U.S.C. \$185 (1964).

$24 I d$. at 103.

25 Id. at 103-04.

26 See Hays, The Future of Labor Arbitration, 74 YALE L.J. 1019, 1022-23 (1965); Jay, Arbitration and the Federal Common Law of Collective Bargaining Agreements, 37 N.Y.U.L. REv. 448, $452-53$ (1962). 
conflicting forums but rather by uncertainty as to whether the arbitrator will follow the federal rule, presumably known to the parties, or ground his award elsewhere. The argument concludes that the latter uncertainty can have the same disruptive effect on collective bargaining as uncertainty as to whether state or federal law will apply. Whether this argument provides a sufficient basis for reversing the treatment generally accorded arbitration awards, recognizing that much of the benefit gained by arbitration will be lost as the role of the courts is enlarged, remains to be seen.

Any answer to this question must begin with a consideration of The Steelworkers' Trilogy. ${ }^{27}$ 'These cases dealt with the uses of arbitration as a means of settling labor disputes. American Manufacturing and Warrior $\mathcal{E}$ Gulf were suits to compel arbitration. At issue in American Manufacturing was whether an employee discharge was arbitrable under the extant collective bargaining agreement. In Warrior \& Gulf the question was whether the employee had reserved the right to "contract out" as a management function or whether he had to submit the matter to arbitration. The gist of the Court's holding in each case was that arbitration would be compelled unless the collective bargaining agreement explicitly withheld the matter from arbitration. In both cases arbitration was ordered. Enterprise Wheel was a suit to enforce an arbitral award. The Court, in ordering the employer to comply with the award, stated: "The federal policy of settling disputes by arbitration would be undermined if the courts had the final say on the merits of the awards." 28

While the three cases contain language which supports both the proponents of the uniformity argument and those who would argue against it, ${ }^{29}$ the overall effect is clearly to place a large amount of discretion with the

27 United Steelworkers of America v. Enterprise Wheel \& Car Corp., 363 U.S. 593 (1960) ; United Steelworkers of America v. Warrior \& Gulf Nav. Co., 363 U.S. 574 (1960); United Steelworkers of America v. American Mfg. Co., 363 U.S. 564 (1960).

28363 U.S. at 596.

29 See, e.g.:

[T] he grievance machinery under a collective bargaining agreement is at the very heart of the system of industrial self-government. Arbitration is the means of solving the unforeseeable by molding a system of private law for all the problems which may arise and to provide for their solution in a way which will generally accord with the variant needs and desires of the parties.

United Steelworkers of America v. Warrior \& Gulf Nav. Co., 363 U.S. 574, 581 (1960).

The process of even frivolous claims may have therapeutic values of which those who are not a part of the plant environment may be quite unaware.

United Steelworkers of America v. American Mfg. Co., 363 U.S. 564, 568 (1960). (Footnote omitted.)

When an arbitrator is commissioned to interpret and apply the collective bargaining agreement, he is to bring his informed judgment to bear in order to reach a fair solution of a problem . . . Nevertheless, an arbitrator is confined to interpretation and application of the collective bargaining agreement; he does not sit to dispense his own brand of industrial justice.

United Steelworkers of America v. Enterprise Wheel \& Car Corp., 363 U.S. 593, 597 (1960). 
arbitrator. ${ }^{30}$ Despite the Court's reasoning in Lucas Flour and the fact that the Trilogy did not confront the precise issue here discussed, ${ }^{31}$ attitudes expressed in the Trilogy must be given great weight.

\section{B. Specific Problem Areas}

\section{Statutory Violations}

It remains now to apply to specific problem areas the arguments for and against the subjection of a labor arbitrator to judicial review and reversal for errors in construing or applying federal law. Perhaps the simplest situation is where the arbitrator, purporting to interpret the contract, orders one of the parties to perform an act which would violate a congressional prohibition. As Professor Williston has said, "where the subject matter of the contract between the parties lies in an area covered by federal law, they necessarily adopt, as a portion of the agreement, the applicable provisions of the particular Act of Congress." 32 Thus to the extent that a collective bargaining agreement orders the commission of an unlawful act, it is void. Therefore, the arbitral award, predicated on the void contract, should be unenforceable. ${ }^{33}$

What case law there is in the area seems to support this result. In Kreindler v. Clarise Sportswear Co.,34 the defendant resisted enforcement of an award on the grounds that enforcement would cause it to violate section 302(a) of the Labor Management Relations Act. ${ }^{35}$ The court held that subsection (c) (5) ${ }^{36}$ exempted the conduct in question and thus the defendant was not ordered to commit an unlawful act. The opinion clearly implies, however, that if the act had been illegal, enforcement would have been denied. ${ }^{37}$

More recently a union brought suit for damages arising out of a labor dispute, and the employer counterclaimed, alleging that the union had violated the terms of an arbitration agreement between them by filing unfair

30 See Report of Sub-Committee on Labor Arbitration Law of Sectron on Labor Relations Law of the American Bar Assoctation, 35 Lab. Arb. 949 (1961); Smith, Arbitrability-The Arbitrator, the Courts and the Parties, 17 ARB. J. 3, 8 (1962) ; Comment, 28 U. CHI. L. Rev. 707 (1961).

31 Of course, Lucas Flour did not confront this precise issue either.

324 Williston, Contracts $\$ 615$ (3d ed. 1961).

33 Put differently, this latter view can be expressed by a hypothetical in which $A$ and $B$ enter into a contract whereby $A$ will pay $B$ to commit an unlawful act, and $B$ then changes his mind. In this situation $A$ cannot go to the courts for enforcement.

34184 F. Supp. 182 (S.D.N.Y. 1960).

3561 Stat. 157 (1947), as amended, 29 U.S.C. \$186(a) (1964).

3661 Stat. 157 (1947), as amended, 29 U.S.C. $\$ 186$ (c) (5) (1964).

37 The court devotes its entire opinion to a discussion of the legality of the contract and the award made pursuant thereto. In this context, we can infer from the following language that the court would not have enforced the award if the arbitrator had ordered the employer to commit an unlawful act:

The fact that the employees of Clarise's contractors cannot share in the payments based on their payrolls [which was alleged to be unlawful by the employer but held lawful by the court] which Clarise has agreed to make does not give Clarise the right to avoid its agreement as illegal.

184 F. Supp. at 184. 
labor practice charges with the National Labor Relations Board. ${ }^{38}$ The court rejected this allegation, holding that "insofar as the arbitration agreement . . . attempted to preclude by contract the Union or its members from filing unfair labor practice charges against the company . . . it is contrary to Federal law and is unenforceable." 39

A slightly different problem is presented when the defense is that the arbitration award violates the public policy of the state in which compliance would take place. For example, in Local 453, Int'l Union of Electrical Workers $v$. Otis Elevator, ${ }^{40}$ an employee had been convicted under New York law ${ }^{41}$ of knowing possession of gambling slips; the employer then discharged the employee for violating the company rule against gambling on the premises. The arbitrator ordered the employee reinstated, and the union brought suit for enforcement under section 301. The Second Circuit, reversing the district court, enforced the award: "[T] here is no substantive principle of federal labor law which authorizes denial of enforcement on the present facts for reasons of public policy." 42

One of the employer's contentions in Otis Elevator was that the reinstatement of the employee exposed the employer to criminal sanctions. The court dismissed that allegation as spurious on the facts of the case; however, this raises an interesting problem-can an arbitral award which forces a party to violate a state statutory prohibition be enforced in federal court? This problem must be distinguished from the situation where the award, while violating the public policy of the state, does not order the violation of a statute. It is one thing to say that where state and federal policies conflict the federal policy should be supreme, but quite another to say that

${ }^{38}$ Local 743, Int'1 Ass'n of Machinists v. United Aircraft Corp., 220 F. Supp. 19 (D. Conn. 1963).

39 Id. at 23. The "federal law" in question was $\$ 10$ (a) of the National Labor Relations Act, 49 Stat. 453 (1935), as amended, 29 U.S.C. $\$ 160$ (a) (1964), which provides:

The Board is empowered . . . to prevent any person from engaging in any unfair labor practice... affecting commerce. This power shall not be affected by any other means of adjustment or prevention that has been or may be established by agreement, law, or otherwise . . . .

40314 F.2d 25 (2d Cir.), cert. denied, 373 U.S. 949 (1963).

41 N.Y. PENAL LAW $\$ 974$.

42314 F.2d at 29 . This principle was explained more fully by Judge Timbers in Jenkins Bros. v. Local 5623, United Steelworkers of America, $230 \mathrm{~F}$. Supp. 871 (D. Conn. 1964), aff'd per curiam, 341 F.2d 987 (2d Cir.), cert. denied, 382 U.S. 819 (1965). The court said:

[A]n arbitration board, pursuant to a collective bargaining agreement, may arbitrate the question of just cause in the discharge of an employee for violation of state gambling laws notwithstanding the existence of a public policy of the state against gambling. . . . [S] uch state policy is not controlling over, but must yield to the substantive principles of national labor law which the federal courts are empowered to fashion-in short, the public policy of the United States as declared by the federal courts in the field of national labor law must prevail over any state public policy asserted to the contrary . . . .

Id. at 872 . This proposition seems clearly correct on its facts; where an arbitral award violates a state's public policy but does not order the employer to violate the state's law, clearly the federal policy of settling labor disputes by arbitration, United Steelworkers of America v. Enterprise Wheel \& Car Corp., 363 U.S. 593, 596 (1960), should control. 
a federal court should order a party, under pain of civil contempt proceedings, either to commit a crime or to do an act which would make him liable for damages in a civil suit. Clearly a federal court should not have the power to put a party to this choice. ${ }^{43}$ Consequently, while an arbitration award which violates the public policy of the state but does not order a statutory violation should be enforced, an award which requires that a statute be violated should not be enforced. ${ }^{44}$

The most difficult problem in the area of statutory violations is the situation where the defendant in the suit for enforcement claims that the award orders him to commit an unfair labor practice. For example, what should a court do when a union sues for enforcement and the employer alleges that the award orders him to discharge an employee who has lost his membership in the union for reasons other than the nonpayment of dues? 45 What makes this situation more difficult than the other "unlawful acts" cases is that here the court would have to make determinations of unfair labor practices in the first instance, a practice which conflicts with the doctrine of primary jurisdiction-that such determinations should be made initially by the National Labor Relations Board. ${ }^{48}$

43 In a recent Supreme Court opinion, Brotherhood of Locomotive Eng'rs v. Chicago, R.I. \& Pac. R.R., 382 U.S. 423 (1966), the Court held that Congress, in passing a statute requiring arbitration between railroads and unions respecting the size of train crews, would not be deemed to have superseded a state statute regulating the size of these crews. The Court said that while Congress has the authority under the commerce clause to supersede such state legislation, Congress must do so explicitly. Similarly, in the hypothetical case posed in the text, there has been no express delegation from Congress to an arbitrator which would allow him to make an award in violation of state law; thus, if he makes such an award, a federal court should deny enforcement. It might be added that were Congress to make such an express delegation to an arbitrator, giving him the authority to supersede state law, there would be serious question as to its constitutionality. See Schechter Poultry Corp. v. United States, 295 U.S. 495 (1935) (delegation to private groups unconstitutional).

One of the problems with the position that a federal court cannot enforce an arbitral award which orders a violation of either state or federal law is the role of the arbitrator. Must he decide, for example, whether the granting of an award to A would force $B$ to commit a crime, or should he leave this job to the courts? It would seem that he should refuse to grant the award only in those situations where it is clear that enforcement would cause violation of law. His area of expertise does not lie in interpreting penal statutes, and thus in all but the clear cases B must get his relief from the courts.

44 This reasoning suggests the conclusion that where the arbitrator orders the violation of state common law, e.g., state law of defamation, his award should not be enforced. It does not seem, however, that this situation will often occur.

45 See Aaron, Arbitration in the Federal Courts: Aftermath of the Trilogy, 9 U.C.L.A.L. REv. 360,373 (1962). The textual reference is to $\$ 8$ (a) (3) of the Labor Management Relations Act, 61 Stat. 140 (1947), 29 U.S.C. \$158(a)(3) (1964), which provides in pertinent part:

[N]o employer shall justify any discrimination against an employee for non-membership in a labor organization ... (B) if he has reasonable grounds for believing that membership was denied or terminated for reasons other than the failure of the employee to tender the periodic dues and the initiation fees uniformly required as a condition of acquiring or retaining membership ....

46 Trailways of New England, Inc. v. Amalgamated Ass'n of Street Employees of America, 343 F.2d 815, 818 (1st Cir.), cert. denied, 382 U.S. 879 (1965); see United States v. Western Pac. R.R. Co., 352 U.S. 59 (1956).

The Trailways case, which stated that the question whether a given set of facts constitutes an unfair labor practice is in the first instance for the Board, should be 
A number of courts have been faced with this problem; the results have been mixed. In Glendale Mfg. Co. v. Local 520, ILGWU, ${ }^{47}$ the Fourth Circuit considered the legality of an award ordering the employer to negotiate on proposed wage increases. The award was handed down on September 24, 1958; six days later the collective bargaining agreement expired, and one day after that the union was decertified as the result of an election held by the Board. Judge Haynsworth, writing for a unanimous court, stated:

it seems . . . that we have the simple case of a minority union seeking to act as the exclusive representative of the employees with respect to their wages for this limited period. If we compel the employer to bargain with the union under these circumstances, we compel the employer and permit the union to commit an unfair labor practice in violation of the rights guaranteed to the employees under $\$ 7.48$

Similar reasoning was employed by the First Circuit in Local 1898, Int'l Ass'n of Machinists v. Brake \& Electric Sales Corp. ${ }^{49}$ The court there held, in construing a contract in the absence of an arbitration clause, that since the employer had a reasonable belief that membership in the union was not accorded to employee Resnick on the same terms and conditions by which other employees could become members, discharge of Resnick by the employer would have been an unfair labor practice. ${ }^{50}$ Thus the court held that there had been no breach of the union security clause

distinguished from the situation where one party brings suit to compel arbitration and the other defends on the ground that if the arbitrator were to hold for the first party he would be ordering the commission of an unfair labor practice. In this situation, the courts have ordered arbitration. See, e.g., Carey v. General Elec. Co., 315 F.2d 499, 508-11 (2d Cir. 1963), cert. denied, 377 U.S. 908 (1964) ; International Union of Electrical Workers v. Westinghouse Elec. Corp., 218 F. Supp. 82 (S.D.N.Y. 1963), aff'd per curiam, 326 F.2d 758 (2d Cir. 1964); Salaried Employees v. Westinghouse Corp., 53 L.R.R.M. 2204 (W.D. Pa. 1963) (held for defendant on other grounds). These cases seem correct; a court should not presume that an arbitrator will render an "unlawful" decision. Moreover, there may be a "therapeutic" value in submitting a case to an arbitrator even though he can only decide it one way. See text accompanying note 79 infra.

47283 F.2d 936 (4th Cir. 1960), cert. denied, 366 U.S. 950 (1961).

$48 \mathrm{Id}$. at 940. Query whether the case is so clear as Judge Haynsworth would have us believe. Until decertification the employer would have the duty to bargain regardless of actual minority if indeed the matter were appropriate for bargaining. It might be thought that deeming the conduct here an unfair labor practice would condone an employer delay: The case is presented here merely as an example of a court willing to forego notions of primary jurisdiction. The court referred the case back to the arbitrator who, it said, could order the employer to negotiate directly with the employees. Ibid.

49279 F.2d 590 (1st Cir. 1960).

$50 \mathrm{Id}$. at 592 . The court felt that the conduct would violate $\$ 8(\mathrm{a})$ (3) of the Labor Management Relations Act, 61 Stat. 140 (1947), 29 U.S.C. \$158(a) (3) (1964), which provides in pertinent part:

[N]o employer shall justify any discrimination against an employee for nonmembership in a labor organization $(A)$ if he has reasonable grounds for believing that such membership was not available to the employee on the same terms and conditions generally applicable to other members.... 
of the contract. The fact that the case originated with the district court rather than with an arbitrator does not undercut its value as showing the court's willingness to overlook notions of primary jurisdiction, at least in certain situations. ${ }^{51}$

The decisions on this point, however, are far from unanimous. In Locals 234 \& 243 , ILGWU v. Beauty Bilt Lingerie, Inc., ${ }^{52}$ the court, without discussion, dismissed on a number of grounds the allegation that enforcement of the arbitrator's award would require violation of section $8(\mathrm{e})$ -the "hot cargo" provision..$^{53}$ One ground for dismissal was the primary jurisdiction of the Board. Thus the court enforced the award without looking into the unfair labor practice charges.

The Supreme Court showed a similar bent in Retail Clerks Int'l Ass'n v. Lion Dry Goods, Inc.54 In that case a non-majority union entered into a "strike settlement" with the employer; the Court enforced the agreement, limiting its discussion to whether such an agreement was cognizable under section 301 . The Court did not even mention the possibility that such conduct might constitute an unfair labor practice ${ }^{55}$ and made only the following statement with regard to the status of the union: "[I] f the federal courts' jurisdiction under $\S 301$ (a) required a preliminary determination of the representative status of the labor organizations involved, potential conflict with the National Labor Relations Board would be increased ...." ${ }_{56}$

Analysis of these cases reveals two courses of conduct which a court might take when faced with the defense that enforcement of an arbitration award will compel one of the parties to commit an unfair labor practice. Glendale held, and Brake $\mathcal{F}$ Electric implied, that where such a defense was raised the court would forego notions of primary jurisdiction and decide the unfair labor practice question for purposes of the enforcement proceeding. On the other hand, in Lion Dry Goods and Beauty Bilt these defenses were ignored; the only question discussed was whether the arbitrator decided the problem submitted to him. A third possibility might be for the court to stay the proceedings before it until the Board has had a chance to rule on whether the conduct was indeed an unfair labor practice. The prerequisites for implementing this alternative would be met, for example, if the employer (assuming he is the defendant in the court pro-

51 It should be noted, however, that the same court which decided Brake \& Electric stated in Trailways of New England, Inc. v. Amalgamated Ass'n of Street Employees of America, 343 F.2d 815 (1st Cir.), cert. denied, 382 U.S. 879 (1965), that questions of the existence of an unfair labor practice are, in the first instance, for the Board. See note 46 sipra and accompanying text.

5248 L.R.R.M. 2995 (S.D.N.Y. 1961).

53 Labor-Management Reporting and Disclosure Act of 1959, 73 Stat. 543, 29 U.S.C. $\$ 158(\mathrm{e})(1964)$.

54369 U.S. 17 (1962).

55 Only a year earlier, in ILGWU v. NLRB, 366 U.S. 731 (1961), the Court had upheld a Board determination that similar conduct constituted an unfair labor
practice.

56369 U.S. at 29. 
ceeding) petitions the Board, alleging that the union is violating section 8 (b) (2) ${ }^{57}$ or one of the other applicable provisions regarding union unfair labor practices. As a final possibility, the court might set aside the award only in those situations where the ordering of an unfair labor practice is clear: for example, where a court is asked to enforce a "hot cargo" clause ${ }^{58}$ identical to others previously declared unlawful by the Board.

By process of elimination the first alternative-that the court forego notions of primary jurisdiction and decide the unfair labor practice question for purposes of the enforcement proceeding-seems the best. ${ }^{59}$ The second would carry with it the possibility that after the court tells a party that he must comply with the terms of an award the party will be faced with further litigation and a Board order to cease and desist from such conduct. It is true that the Board, in International Harvester Co., ${ }^{60}$ held that it would defer to the arbitrator's determination that the conduct involved would not constitute an unfair labor practice in situations where "the arbitration proceedings were [not] tainted by fraud, collusion, unfairness or serious procedural irregularities . . . ." 61 But the arbitrator's determination is not the final word in all cases. In many situations the arbitrator would not want to become embroiled in the decision whether certain conduct constitutes an unfair labor practice; his area of expertise lies in interpreting contracts, not statutes. In those situations where the arbitrator makes no findings as to an alleged unfair labor practice, International Harvester would be inapplicable and the defendant in the court proceeding would be subject to further litigation before the Board. Even if this defendant petitioned the Board at the time of the issuance of the award and obtained from the court a stay of the enforcement proceeding, as suggested in the third possibility above, the parties would be subject to the expense of dual litigation and delay before the litigation is settled. This expense and delay would, to a great extent, undermine one of the major functions of labor arbitration.

Although some of this expense, delay and dual litigation may be eliminated in some cases, if the court is permitted to decide the unfair labor practice defense only where the answer is clear, the presence of these problems in cases where existence of an unfair labor practice is uncertain must

57 Section 8(b) (2), 61 Stat. 141 (1947), as amended, 29 U.S.C. $\$ 158(b)$ (2) (1964), is singled out because in a great many cases the employer's complaint will be that the union is attempting to cause him to violate $\S 8(\mathrm{a})(3)$. Section 8 (b) (2) provides:

(b) It shall be an unfair labor practice for a labor organization or its agents

... (2) to cause or attempt to cause an employer to discriminate against

any employee in violation of subsection (a) (3) of this section ...

5873 Stat. 543 (1959), 29 U.S.C. \$158(e) (1964).

59 Implicit in this conclusion is the assumption that the judiciary, even in unclear cases, will decide the issue correctly more often than not. This assumption seems justified by the fact that the courts of appeals which review the Board unfair labor practice findings would here review the enforcement proceedings.

60138 N.L.R.B. 923 (1962), aff'd sub nom. Ramsey v. NLRB, 327 F.2d 784 (7th Cir.), cert. denied, 377 U.S. 1003 (1964).

61 Id. at 927 . 
be weighed against the dangers of allowing the courts to decide all such cases. The court would be deciding the case only for the purpose of determining whether the arbitrator's award should be enforced and thus would not be robbing the Board of its jurisdiction to police such practices. ${ }^{62}$ Moreover, while it is true that another of the purposes of the primary jurisdiction rule-to have a single agency develop a uniform set of ruleswould be somewhat impaired, the extent of impairment would not seem to be very great. The Board would not be bound by the rules enunciated by the court, either in the same case if the court held that the conduct did not constitute an unfair labor practice and the Board disagreed, or in later cases involving similar facts. ${ }^{63}$ Further, a court would most likely do its best to apply rules already formulated by the Board; this would be another factor mitigating the absence of a single set of rules. ${ }^{64}$

There is one situation, of course, where the Board would not have the opportunity to rectify an error committed by a court-where the court concludes that the employer's conduct constitutes an unfair labor practice and refuses to enforce the award, and the Board would have found otherwise. While this is certainly a possibility and could be looked upon as having detrimental effects on the arbitration process, the alternative of deferring in all but the very clear cases ${ }^{65}$ would seem more detrimental in terms of delay and expense. On balance then the wiser course would be for the courts to forego notions of primary jurisdiction in all section 301 actions involving arbitral awards. ${ }^{66}$

The above discussion demonstrates that in all situations where the labor arbitrator's award orders one of the parties to commit an unlawful act, the award should not be enforced. This conclusion, however, is no victory for the proponents of the uniformity argument. ${ }^{67}$ Rather it is reached because the courts would deem the contract itself as unlawful and therefore unenforceable. ${ }^{68}$ The real test of the uniformity argument comes

6249 Stat. 453 , as amended, 29 U.S.C. $\$ 160$ (a) (1964) provides:

The Board is empowered ... to prevent any person from engaging in any unfair labor practice affecting commerce. This power shall not be affected by any other means of adjustment or prevention that has been or may be established by agreement, law, or otherwise....

63 Ibid.

64 The Board could apply its reasoning in International Harvester $C_{0}$, see text accompanying notes $60-61$ supra, to the situation where the court decided the unfair labor practice in the first instance. The decision of when to defer to the court's determination would be solely at the discretion of the Board.

65 And who is to say which cases are clear? Judge Haynsworth deemed Glendale a clear case-query whether it is. See note 48 sipra.

66 See Sovern, Section 301 and the Primary Jurisdiction of the NLRB, 76 HARv. L. Rev. 529 (1963); cf. Smith v. Evening News Ass'n, 371 U.S. 195 (1962).

Professor Sovern supports the result in Lion Dry Goods but thinks that this is the only type of case, i.e., a "no-majority" case, where the court should ignore an unfair labor practice defense. Sovern, supra at 562-65.

${ }^{67}$ See notes 22-26 sipra and accompanying text.

${ }^{68}$ See notes 32-33 supra and accompanying text. 
in the area next to be examined-where the defense in the enforcement proceeding is that the award does not comport with court decisions construing similar contract provisions.

\section{Noncompliance with Court-made Law}

In Zdanok v. Glidden Co., ${ }^{69}$ the Second Circuit, in construing a contract in the absence of an arbitration clause, decided that the seniority rights of certain employees had "vested" and could be enforced even after the contract between the employer and the union had terminated. Should a court in the Second Circuit, or in any circuit, refuse to enforce an arbitrator's award which does not comply with $Z$ danok in a case where the contract and facts with which he deals are indistinguishable from $Z$ danok? Should it make any difference how well "established" the rule in question is?

It would seem that before the uniformity argument could be deemed at all persuasive, the federal rule in question would have to be well established. ${ }^{70}$ For if there is a dispute among the various federal courts as to the proper interpretation of a certain type of labor contract, it could hardly be argued that the arbitrator contributed to the uncertainty of the parties' expectations by failing to follow one of the "rules." 71 Even assuming that the "rule" at issue is "established," however, it is far from clear that the uniformity consideration should control. This problem has not yet been considered by the courts. One commentator has suggested that once the substantive law has been incontrovertibly "established" in the federal courts, the arbitrator should consider himself bound or at least authoritatively guided by that law. These views seem not to be limited to labor arbitration and would provide guidelines for commercial arbitration as well. ${ }^{72}$ At any rate, this does not solve our problem; even if arbitrators should consider themselves guided, or bound, by federal law, what should

69288 F.2d 99 (2d Cir. 1961), aff'd, 370 U.S. 530 (1962).

70 This condition is not at all clear with regard to Zdanok. See, e.g., Proctor \& Gamble Independent Union v. Proctor \& Gamble Mfg. Co., 312 F.2d 181 (2d Cir. 1962), cert. denied, 374 U.S. 830 (1963); Oddie v. Ross Gear \& Tool Co., 305 F.2d 143 (6th Cir.), cert. denied, 371 U.S. 941 (1962).

71 This reasoning might lead to the conclusion that only when the Supreme Court has spoken can there be an "ascertained" federal rule. Until such time as the Court has spoken, there is likely to be a dispute among the circuit courts and the state courts applying federal law under § 301 .

72 Katz, Discussion of - Feinberg, Do Contract Rights Vest?, in LABor ARBTrRATION AND Industrial Change 223, 229-30 (Kahn ed. 1963). Mr. Katz stated:

Arbitrators, like judges, are clothed with great discretion but their judgment must be exercised within a framework of law. Each arbitrator is not a separate solar system unattached to the national labor policy and its constitutional interpreters; he operates also within the framework of that policy as delineated by law and interpreted and applied by the courts of the United States. Any other concept of arbitral power represents basically an unacceptable usurpation of judicial authority and would be essentially a major step toward industrial anarchy. It would be difficult to conceive a policy more likely to destroy the institution of voluntary arbitration.

Ibid. See note 82 infra. 
a court do if an arbitrator advertently or inadvertently does not so bind himself?

Dean Smith has suggested a possible answer to this question. In introducing the problem, he has said:

[W] are here involved in an area of special difficulty in view of the ultimate control which the federal judiciary has over the arbitration process, the role ascribed to it in developing a federal law concerning the labor agreement, and the disposition of the Supreme Court, evident in areas such as the delineation of federal and state authority, to regard as desirable a pattern of national uniformity of labor law. ${ }^{73}$

For Dean Smith, who restricted his analysis to situations where the Supreme Court has spoken, the answer would seem to turn on whether we view the Court's decision as only an interpretation of the contract before it or whether the decision carries implications for federal labor law. ${ }^{74}$ If the former view were adopted, the arbitrator's award would be enforced whether or not he followed the Court's decision; if the latter were adopted, it would not.

Getting back to the specific problem raised by the Zdanok case, and even assuming that the rule in question is well established, the uniformity argument should not prevail. Initially it should be kept in mind that if the parties had felt any great need for certainty, i.e., if any uncertainty as to whether the arbitrator would apply federal law was disrupting the collective bargaining process, they could easily have removed the problem by providing in the contract that in any dispute over the meaning of the terms, the arbitrator was correctly to apply federal substantive law. If the parties had done this and the arbitrator had then handed down an award which did not comport with federal law, the court could deny enforcement on the simple ground that the arbitrator had exceeded the scope of submission. To the extent that the parties have not so bound the arbitrator, they have shown a preference for his unrestricted judgment even at the cost of uncertainty. More importantly, the parties have shown a desire to settle their disputes in the most expeditious manner possible, without the delay and expense of litigation. Granting to the courts a broad scope of review in this type of case would eliminate the value of the arbitration process and could cause the process to fall into disuse. This would be a very heavy price to pay considering Mr. Justice Goldberg's words that "labor arbitration fulfills one vital function: the substitution of the judgment of a third party for the use of economic force." 75

Thus whether or not we accept Dean Smith's dichotomy and brand $Z$ danok a case where the court has merely interpreted the contract before

73 Smith, Arbitrators and Arbitrability, in Labor ArbItratron aNd INDUSTRIAL Change 75, 93 (Kahn ed. 1963).

74 Ibid.

75 See note 20 supra and accompanying text. 
it, it seems that in a case where all that is involved is whether the arbitrator failed to follow federal court standards in interpreting the terms of the contract before him, the reviewing court should nevertheless enforce the contract.

Another context in which this problem appears is the question whether an arbitrator, given the authority by the parties to decide the question of arbitrability, is governed, as the courts applying federal law have been since the Trilogy, by the presumption favoring arbitrability. The Court in Warrior $\mathcal{E}$ Gulf said that arbitration would be compelled under a general arbitration clause unless the subject matter was explicitly withheld from the arbitrator by another clause of the contract, or unless there was "forceful evidence of the purpose to exclude." 76 The question arises whether a court should overturn an arbitrator who has not bound himself by this presumption in a situation where the contract states that the arbitrator is to determine the question of arbitrability.

In a recent district court case, Metal Products Union v. The Torrington $\mathrm{Co}_{0 .}{ }^{77}$ the court upheld the arbitrator's determination of no arbitrability on the ground that the arbitrator had found, through "extrinsic evidence," that the parties had reached an agreement that the dispute would not be arbitrable. However, the court indicated in dictum that an arbitrator, when determining substantive arbitrability, will be held to the same standard as a court under Warrior \& Gulf. ${ }^{78}$ This dictum seems questionable, for in addition to the reasons discussed above as to why an arbitrator should not be overturned for failing to comply with federal court-made law, it is necessary to consider the reason for the rule in Warrior \& Gulf. Mr. Justice Douglas' Trilogy opinions are replete with language indicating the "therapeutic" service that an arbitrator can perform-soothing the feelings of both sides and thus preventing industrial strife. ${ }^{79}$ This is a fine rule when the issue is whether a question should be submitted to an arbitrator in the first instance. However, when the case is already before the arbitrator on the question of arbitrability, he can perform his "therapeutic" service at that time; it is not necessary for him to reach the merits of the dispute to do so. ${ }^{80}$ Thus Dean Smith has concluded on this question that the courts "settle issues of arbitrability only at the level of the propriety of judicial interception or review of the arbitration process. They lay down rules for the courts, not for the arbitrators . . . ." 81

76 United Steelworkers of America v. Warrior \& Gulf Nav. Co., 363 U.S. 574, $584-85$ (1960).

77242 F. Supp. 813 (D. Conn. 1965).

78 Id. at $821 \mathrm{n} .26$.

79 See, e.g., United Steelworkers of America v. Warrior \& Gulf Nav. Co., 363 U.S. 574, 578 (1960) ; United Steelworkers of America v. American Mfg. Co., 363 U.S. 564,568 (1960).

80 As a practical matter, one might try to imagine in how many cases an arbitrator will hold a matter not arbitrable where the question is at all doubtful.

81 Smith, op. cit. supra note 73, at 92. The argument that in the Trilogy the Supreme Court was clearly shaping federal labor policy and that this policy must govern arbitrators, not for reasons of uniformity but for the same reasons we feel 
Thus it seems that labor arbitrators should be bound by federal law, subject to the penalty of having their awards overturned only in cases where the award would order one of the parties to commit an unlawful act. In all other cases the gain in uniformity would be heavily outweighed by the additional delay and expense which would be a concomitant of wider judicial review. ${ }^{82}$ Moreover, a wider scope of review would cut deeply into the congressional policy-expressed in section 203(d) of the Labor Management Relations Act-favoring "final adjustment" by the parties. ${ }^{83}$

that an arbitrator cannot order a party to violate a statute, must also fail. Putting aside Dean Smith's observation that the presumption was not meant to apply to arbitrators, there is the additional problem that in this situation the contract cannot be deemed unlawful. The rule of the Trilogy, although it shapes federal policy, is still a rule of construction; it is not a standard which a contract must meet or be held unlawful. Therefore, in all such decisions shaping federal policy, see, e.g., John Wiley \& Sons, Inc. v. Livingston, 376 U.S. 543 (1964), only "uniformity" can be argued and, as has been suggested, uniformity cannot be argued persuasively.

82 This is not to suggest, of course, that an arbitrator should not look to a federal court, or any other authority he deems appropriate for guidance in reaching his decision. However, since it is his decision for which the parties have contracted, the arbitrator should not hesitate to disregard any court decision which he thinks incorrect or inappropriate as applied to the case before him.

8361 Stat. 154, as amended, 29 U.S.C. $\$ 173(d)$ (1964). This section provides:

Final adjustment by a method agreed upon by the parties is declared to be the desirable method for settlement of grievance disputes arising over the application or interpretation of an existing collective-bargaining agreement. 